\title{
Luka w podatku od towarów i usług jako zagrożenie dla bezpieczeństwa narodowego
}

\author{
Tax gap in value added tax as a risk for national security
}

\section{Streszczenie:}

W artykule zawarte zostały rozważania dotyczące zagadnień z pogranicza bezpieczeństwa narodowego i szeroko rozumianego prawa budżetowego. W toku wywodu następuje prezentacja podstawowych pojęć oraz powiązanie ryzyka płynącego $\mathrm{z}$ istniejącej luki w podatku od towarów i usług z zagrożeniem dla bezpieczeństwa ekonomicznego kraju. Artykuł zakończony został zestawieniem najważniejszych wniosków.

Słowa kluczowe: bezpieczeństwo narodowe, podatek od towarów i usług, VAT, luka w VAT, budżet

\begin{abstract}
:
The article contains considerations regarding issues on the borderline of national security and broadly understood budget law. In the course of the presentation, the basic concepts are presented and the risk derived from the gap in goods and services tax is connected with national security threats. The article ends with a synthesis of the most important conclusions.
\end{abstract}

Keywords: national security, tax on goods and services, VAT, VAT gap, budget

\section{Wprowadzenie}

Bezpieczeństwo narodowe Rzeczypospolitej Polskiej (dalej: RP) należy rozpatrywać szeroko i z uwzględnieniem wieloaspektowości 
Marek Słupczewski - Luka w podatku od towarów...

tego pojęcia. Jest ono nierozerwalnie związane z budżetem państwa i jego finansowaniem. Przy próbach jego zapewnienia znaczenia nabiera bowiem poza aspektem społecznym i prawnym także aspekt ekonomiczny. Obecnie rozpatruje się to pojęcie szeroko, nie tylko z uwzględnieniem czynników, które przychodzą na myśl jako pierwsze przy definiowaniu zasadniczych środków zapewnienia bezpieczeństwa narodowego, takich jak chociażby siła militarna państwa, lecz również koncentruje się uwagę na jego aspektach geoekonomicznych, geopolitycznych czy też społecznych ${ }^{1}$.

W dzisiejszych czasach kwestie bezpieczeństwa narodowego można rozważać dopiero po zagwarantowaniu środków na realizację zadań mających sprzyjać jego zapewnieniu. Nie jest to zjawisko nowe, już w czasach historycznych mieszkańcy jednej osady wspólnymi siłami utrzymywali drużynę książęcą, która miała zapewnić ochronę terytorium.

Warto sobie wyobrazić w ujęciu modelowym gospodarkę, która posiadając obfite zasoby finansowe, bez najmniejszych wysiłków jest w stanie zabezpieczyć wszelkie potrzeby społeczności. Wówczas dyskusja o tym, jak rozdystrybuować ograniczoną ilość środków traci na znaczeniu. W gospodarkach o ograniczonych zasobach budżetowych, do których w zasadzie zaliczyć należy wszystkie istniejące współcześnie państwa, dużego znaczenia nabierają rozważania na temat dylematu polegającego na wyborze na co przeznaczyć środki, z czego zrezygnować, które zadania można odłożyć w czasie. Bardzo istotna jest tu zasada kosztów alternatywnych ${ }^{2}$, szczególnie w przypadku wydatków na cele sprzyjające zapewnieniu bezpieczeństwa narodowego. Za każdym razem przeniesienie części ograniczonych zasobów na realizację jednego zadania odbywa się kosztem innego. Dyskusja ta ma jednak znaczenie o tyle wtórne, że dotyczy dalszej redystrybucji przeznaczonej w budżecie kwoty bądź to na pewne zadanie, bądź to

\footnotetext{
${ }^{1}$ D. Kowalski, Współczesne aspekty bezpieczeństwa ekonomicznego państwa [w:] R. Szynowski, M. Karpiuk (red.), Bezpieczeństwo narodowe Rzeczpospolitej Polskiej w świetle prawa wewnętrznego i międzynarodowego, Warszawa 2011, s. 292.

2 G. N. Mankiv, M. P. Taylor, Mikroekonomia, Warszawa 2009, s. 63.
} 
w obrębie konkretnego zadania. Przykładowo planowane w 2017 r. wydatki na obronę narodową wyniosły niecałe 30 miliardów złotych, co stanowiło prawie $10 \%$ zgromadzonych w budżecie środków3 ${ }^{3}$. Jest to dziedzina silnie sprzężona $\mathrm{z}$ bezpieczeństwem narodowym, często będąca przedmiotem dyskusji publicznej, a stosunek kandydatów do parlamentu do strategii obronnej pozwala bądź zjednać sympatię wyborców, bądź utracić ich głosy. W praktyce jednak zagadnienie to jest mocno uzależnione od polityki fiskalnej państwa, jej efektywności oraz stosunku i świadomości obywateli. Ujmując to zagadnienie w możliwie prosty sposób, należy stwierdzić, że erozyjna działalność obywateli wobec budżetu polegająca w skrócie na niepłaceniu podatków w negatywny sposób wpływa na możliwości wykonania budżetu i stanowi swoisty zamach na bezpieczeństwo narodowe państwa. Uszczerbek rzędu kilkuset tysięcy złotych zaoszczędzonych bądź wyłudzonych przez obywatela w skali budżetu prawie 40 milionowego kraju wydaje się z pozoru niezauważalny, jednak przy odpowiedniej skali kwotowej jak i dużej liczbie podmiotów, oznacza ogromną utratę efektywności. Co więcej, każde, nawet drobne uszczuplenie kwoty zasilającej budżet, przy założeniu racjonalności wydatkowania środków budżetowych przez uprawnione podmioty skutkuje tym, że polscy obywatele zostaną słabiej przeszkoleni, polskie siły zbrojne będą mogły rzadziej wymienić sprzęt obronny lub też mniejsza będzie pula środków stanowiących rezerwy na wypadek kryzysu. Przykłady te można wyliczać w nieskończoność. Oczywistym jest, że każda dodatkowa jednostka pieniężna może potencjalnie sprzyjać poprawie bezpieczeństwa narodowego.

Celem artykułu jest zaprezentowanie związku między luką w podatku od towarów i usług a bezpieczeństwem narodowym.

Pierwsza część artykułu została poświęcona prezentacji pojęcia bezpieczeństwa narodowego oraz ogólnym rozważaniom związanym $\mathrm{z}$ ryzykiem wyłudzeń $\mathrm{w}$ polskim systemie podatkowym. $\mathrm{W}$ dalszej

\footnotetext{
3 Ustawa budżetowa na rok 2017 z dnia 16 grudnia 2016 r. (Dz. U. 2017 r., poz. 108).
} 
Marek Słupczewski - Luka w podatku od towarów...

kolejności przedstawiono ogólne rozważania na temat luki w podatku od towarów i usług (dalej: VAT). Na potrzeby niniejszego artykułu za lukę w podatku od towarów i usług uznaje się lukę ekonomiczną postrzeganą jako różnicę między oczekiwanym dochodem z tytułu podatku VAT a kwotą otrzymaną. Po dokonaniu powyższego następuje powiązanie negatywnych aspektów dochodowych podatku VAT z zagrożeniem dla bezpieczeństwa narodowego.

Poruszona tematyka jest bardzo szeroka i z pewnością nie wyczerpuje się w ramach niniejszego artykułu. $Z$ tego też względu w drugiej części wywodu uwaga została skoncentrowana na wyłudzeniach związanych z podatkiem od towarów i usług jako reprezentatywnym i zarazem największym przykładem uszczuplenia budżetowego. Uszczuplenia, które w bezpośredni sposób przekłada się na osłabienie finansów państwa oraz docelowo bezpieczeństwa narodowego.

Powyższa teza nie należy do dyskusyjnych i została sformułowana chociażby w raportach o bezpieczeństwie w Polsce w 2015 r. i 2016 r., z których wynika, że „największą sferą aktywności zorganizowanych grup przestępczych jest przestępczość ekonomiczna, która powoduje najwyższe straty dla budżetu państwa i godzi w bezpieczeństwo ekonomiczne Polski przez zmniejszenie wpływów, uzyskiwanie nienależnych zwrotów, wyłudzanie dopłat (w tych obszarach szczególnie istotne pozostają zagrożenia przestępczością związaną z podatkiem VAT oraz akcyzą), jak i sektora prywatnego - przez bezpośrednie zmniejszenie dochodów oraz spadek konkurencyjności w porównaniu z firmami z tzw. szarej strefy czy zaniżania kosztów przez podmioty gospodarcze działające z naruszeniem prawa"4. Dalej w raporcie można przeczytać, że „szeroko rozumiana przestępczość podatkowa, w szczególności dotycząca podatku VAT oraz podatku akcyzowego, generuje najwyższe straty dla budżetu państwa i godzi w jego bezpieczeństwo ekonomiczne".

\footnotetext{
4 Ministerstwo Spraw Wewnętrznych i Administracji, Raport o bezpieczeństwie w Polsce $w 2015$ r., Warszawa 2015 r., s. 85.
} 
W artykule zastosowano metodę studiów literaturowych oraz prawno-dogmatyczną.

\section{Pojęcie bezpieczeństwa narodowego}

Pojęcie bezpieczeństwa jest rozmaicie rozumiane w różnych kręgach kulturowych, społecznych, religijnych. Uprawnionym wydaje się pogląd, że każda jednostka lub zbiorowość, świadomie bądź też nie, dysponuje jego własną definicją. $W$ nauce stosunków międzynarodowych wyróżnia się bezpieczeństwo militarne, ekonomiczne, społeczne, kulturowe, ekologiczne i inne ${ }^{5}$. Można je ogólnie rozumieć jako poczucie wolności przed zagrożeniami.

$\mathrm{Na}$ początku rozważań związanych z bezpieczeństwem narodowym należy pochylić się nad dwoma pojęciami, narodu i państwa. Pojęcia te były szeroko dyskutowane w doktrynie i błędnym byłoby stwierdzenie, że udało się wypracować ostateczne i niebudzące wątpliwości ich definicje. Celem jednak zachowania należytej systematyki należy krótko wskazać na główne cechy tych pojęć.

Dla potrzeb artykułu za naród będę uważać „,społeczność zamieszkującą dane państwo, którą łączą pewne wartości, takie jak wspólnota terytorialna, więzi historyczne, interesy, porządek prawny, język urzędowy i kilka innych cech. Pojęcie to ulega nieustannemu rozszerzaniu. Z państwem kojarzymy zaś "podmiotowość narodową owej terytorialnej konstrukcji społecznej«"6. Państwo, jako niewyizolowana struktura stanowi jeden z elementów stosunków międzynarodowych7.

Pojmowane szeroko pojęcie bezpieczeństwa narodowego zostało zdefiniowane przez S. Dworeckiego jako „stan stabilności wewnętrznej i suwerenności państwa, który odzwierciedla braki występowania jakichkolwiek zagrożeń (w sensie zaspokajania podstawowych po-

\footnotetext{
5 W. Kitler, Bezpieczeństwo narodowe, Podstawowe kategorie, dylematy pojęciowe i próba systematyzacji, „Towarzystwo Wiedzy Obronnej. Zeszyt Problemowy” 2010, nr 1 (61), s. 17.

6 Ibidem, s. 14.

${ }^{7}$ Ibidem, s. 6.
} 
Marek Słupczewski - Luka w podatku od towarów...

trzeb egzystencjalnych i behawioralnych społeczeństwa oraz traktowania państwa jako suwerennego podmiotu w stosunkach międzynarodowych)"8. Definicja ta jest na tyle szeroka, że próba wyodrębnienia w budżecie państwa wydatków, które najpełniej sprzyjają jej realizacji, wydaje się trudna.

Istotnym jest również rozróżnienie dwóch pojęć, bezpieczeństwa państwa i bezpieczeństwa narodowego. W doktrynie wskazuje się, że „bezpieczeństwo państwa to termin i kryjące się pojęcie właściwe każdemu państwu, bezpieczeństwo narodowe rozszerza istotę bezpieczeństwa państwa o wartości i potrzeby bliskie jednostce i różnym grupom społecznym, a w konsekwencji działania na rzecz ich realizacji, właściwe dla państwa demokratycznego (...), pojęcie bezpieczeństwa narodowego rozszerza tradycyjne rozumienie bezpieczeństwa państwa związane z realizacją funkcji państwa na rzecz zachowania terytorium, przetrwania narodu, zachowania suwerennej władzy oraz ładu wewnętrznego i porządku prawnego o ochronę i obronę wartości, potrzeb, a także wsparcie realizacji celów i interesów właściwych jednostkom i grupom społecznym, z grupą państwową włącznie" 9 . „Bezpieczeństwo narodowe jest najważniejszą wartością, potrzebą narodową i priorytetowym celem działalności państwa, jednostek i grup społecznych"10.

\section{Rozważania ogólne dotyczące wyłudzeń w polskim systemie podatkowym oraz budżetowe znaczenie podatku od towarów i usług}

Jakiekolwiek formy uchylania się od opodatkowania, generalnie rozumianego jako działania prowadzącego do uszczuplenia budżetowego, nie są pożądane w żadnym państwie. Niezależnie od motywów po-

\footnotetext{
8 S. Dworecki, Zagrożenia bezpieczeństwa państwa, Warszawa 1994, s. 16.

${ }^{9}$ W. Kitler, Bezpieczeństwo narodowe..., op. cit., s. 22-23.

10 Ibidem, s. 25.
} 
datników ${ }^{11}$ ich rezultat dla budżetu w każdym przypadku jest jednakowy i skutkuje obniżeniem efektywności organizmu państwowego.

System podatków mających najistotniejsze znaczenie budżetowe w Polsce, a których pobór może stanowić potencjalnie największe szanse jak i zagrożenia dla bezpieczeństwa narodowego, składa się z kilku elementów. Mimo mnogości danin publicznych w postaci opłat i podatków, znaczna ich część posiada marginalne znaczenie budżetowe. Przedstawione to zostało na Wykresie 1, na którym zobrazowano wysokość wpływów budżetowych z poszczególnych danin.

Planowane w 2017 r. dochody budżetowe wyniosły 325 428, 002 mln złotych. Tym samym dochody z tytułu podatku od towarów i usług stanowiły 44\% całego budżetu12. Co więcej, w latach 2003 2013 udział podatku od towaru i usług $\mathrm{w}$ dochodach budżetowych systematycznie przekraczał 40\% (z wyjątkiem 2009 r.) ${ }^{13}$. W niektórych latach to właśnie wysokie wpływy z tytułu podatku od towarów i usług wpływały na bardzo dobrą pozycję budżetu państwa. Jest to ponad dwukrotnie wyższa kwota niż z tytułu podatku akcyzowego i kilkakrotnie wyższa niż z tytułu podatku dochodowego od osób fizycznych czy też podatku dochodowego od osób prawnych.

Dochody z tytułu pozostałych podatków mają marginalne znaczenie. Charakterystyczne jest, że wobec innych rozwiniętych państw Polska plasuje się wysoko pod względem uzależnienia od wpływów z tytułu podatku VAT ${ }^{14}$.

${ }^{11}$ E. Kotowska, Ochrona interesów finansowych państwa w zakresie dochodów publicznych w świetle polskich regulacji „antyrajowych”, [w:] R. Szynowski, M. Karpiuk (red.), Bezpieczeństwo narodowe..., op. cit., s. 223.

$12 \mathrm{~W}$ budżecie na $2017 \mathrm{r}$. dochody z tytułu podatku od towarów i usług oszacowano na 143483.000 milionów złotych.

13 P. Jamróz, Luka w podatku od towarów i usług - zagrożenia i kierunki zmian polityki fiskalnej $w$ strefie euro i $w$ Polsce, Sopot 2015, s. 10.

${ }_{14}$ F. Schneider, K. Raczkowski, Sfera nieoficjalna w gospodarce, „Infos”, 2013, nr 21, s. 3. 
Marek Słupczewski - Luka w podatku od towarów...

Wykres 1. Planowane dochody budżetowe z tytułu poszczególnych podatków w Polsce w mln zł w 2017 r.

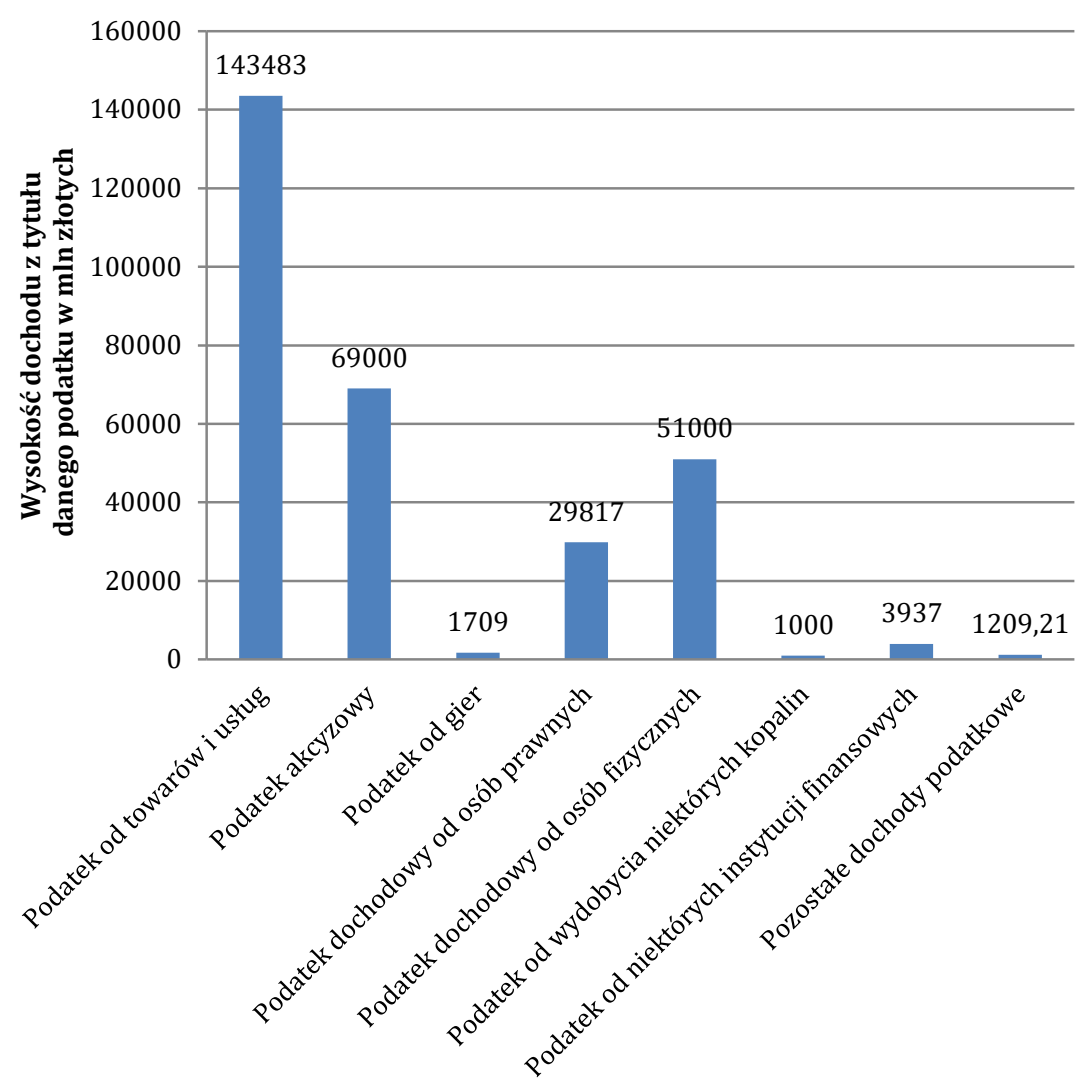

Źródło: Opracowanie własne na podstawie danych zawartych w ustawie budżetowej na rok 2017 r. z dnia 16 grudnia 2016 r. ${ }^{15}$

Na znajdującym się powyżej wykresie został wyodrębniony podatek od gier, podatek od wydobycia kopalin oraz podatek od niektórych instytucji finansowych. Natomiast reszta dochodów podatkowych znajduje się pod zbiorczym hasłem „pozostałych dochodów podatkowych” ze względu na pomijalne znaczenie dla budżetu państwa. Jak

15 Tekst jedn. Dz.U. z 2017 r. poz. 108. 
wynika z powyższego, szczególną uwagę należy poświęcić podatkowi od towarów i usług i szerzej opisać zjawisko luki ekonomicznej w tym podatku. Uzasadnienie fakt ten znajduje nie tylko w istotnym znaczeniu tego podatku dla polskiego budżetu, lecz także dla budżetu Unii Europejskiej (w 2014 r. dochody z VAT stanowiły 1 bilion euro, co odpowiadało $7 \%$ unijnego $\mathrm{PKB}^{16}$ ).

Odnosząc się krótko do znaczenia budżetowego tego podatku, należy stwierdzić, że jego znaczny udział we wpływach „skutkuje tym, iż wskaźniki dynamiki dochodów z tytułu podatku od towarów i usług wpływają na wysokość wskaźników dynamiki dochodów podatkowych budżetu państwa, jak też dynamiki dochodów ogółem budżetu państwa"17. W praktyce zaobserwowano, że chociażby występujące w 2009 i 2013 r. trudności w realizacji budżetu po stronie dochodowej były wynikiem nagłego spadku wpływów z tytułu podatku od towarów i usług ${ }^{18}$. W rezultacie należało znowelizować ustawę budżetową i zaplanować mniejsze dochody ${ }^{19}$. Zauważalny jest również wzrost zaległości podatkowych z tytułu podatku VAT20.

Zawężenie dyskusji do podatku VAT poparte jest ponadto faktem, że wspomniana skala wyłudzeń ograniczona jest wyłącznie „fantazją i przebiegłością" uczestników obrotu, co w oczywisty sposób charakteryzuje specyfikę tego podatku.

16 T. Tratkiewicz, Luka w VAT - sposoby przeciwdziałania w Polsce i Unii Europejskiej, Ministerstwo Finansów, Departament Podatku od Towarów i Usług, „Zeszyty Naukowe Uniwersytetu Ekonomicznego w Katowicach - Studia Ekonomiczne”, Katowice 2016, s. 294.

17 T. Budzyński, Fiskalne aspekty podatku od towarów i usług w Polsce, „Annales Universitatis Marie Curie-Skłodowska Lublin - Polonia" 2016, Vol. L, 1 Section H, s. 612.

18 Odpowiedź podsekretarza stanu w Ministerstwie Finansów, p. M. Grabowskiego z upoważnienia ministra z dnia 5.10.2012 r. na interpelację $\mathrm{nr} 8642 \mathrm{w}$ sprawie luki podatkowej w podatku od towarów i usług oraz strat finansowych w związku z nią poniesionych [dostęp: 24-02-2018]. http://sejm.gov.pl/sejm7.nsf/interpelacja. xsp?typ=INT\&nr $=8642 \&$ view $=$ null

19 T. Budzyński, Fiskalne aspekty..., op. cit., s. 613.

${ }^{20}$ Ibidem, s. 616. Aktualnie wydaje się, że na skutek szeregu działań wzrost rozmiaru luki udało się co najmniej spowolnić. 
Marek Słupczewski - Luka w podatku od towarów...

Dzieje się tak z tego względu, że w przypadku chociażby podatków dochodowych kwota oszustw podatkowych wiąże się z pewnym substratem materialnym, jakim jest dochód. $W$ tych bowiem przypadkach, żeby doszło do uszczuplenia budżetowego, w pierwszej kolejności podmiot musi wygenerować przychód, który, w najprostszym ujęciu, będzie wyższy od poniesionych przez niego kosztów. Tym samym dopiero gdy podatnik wykaże się efektywnością, będzie mógł podjąć rozważania na temat ewentualnej optymalizacji podatkowej21. Z tego też względu pula kwot narażonych na wyłudzenia jest ograniczona. W przypadku natomiast podatku od towarów i usług, jak też wykazały już pierwsze sukcesy służb administracji skarbowej w latach 20162017, wysokość potencjalnych wyłudzeń ograniczona jest wyłącznie inicjatywą oszustów podatkowych.

Z punktu widzenia nagannej działalności części podatników bez znaczenia pozostaje fakt, czy fikcyjny obrót będzie dotyczył kwoty o wartości dziesięciu, czy też stu milionów złotych. Co więcej, organizatorami procederu mogą zostać podmioty nieposiadające szczególnych kwalifikacji, z różnych branż. Należy również zwrócić uwagę, że nawet gdy podmiot dokonuje wyłudzeń w mało efektywny sposób, zazwyczaj i tak dochodzi do uszczuplenia budżetowego. Dzieje się tak, gdyż w momencie, gdy organy będą dysponować wystarczającą wiedzą, by dokonać zabezpieczenia jego majątku, zazwyczaj jest już zbyt późno, by udało się odzyskać choć część środków. W tym miejscu dodać należy, że obecnie administracja skarbowa otrzymuje nowe uprawnienia, które pozwolą przykładowo na pewien czas zablokować środki na rachunkach bankowych przedsiębiorców. Mimo potencjalnie dobrego kierunku zmian nie należy zapominać o negatywnych skutkach nieprawidłowego korzystania $\mathrm{z}$ uprawnień ${ }^{22}$. Praktyka wskazuje, że w przeszłości niejednokrotnie dochodziło do zastosowa-

\footnotetext{
${ }^{21}$ Na przykład poprzez korzystanie z rajów podatkowych.

${ }^{22}$ Mowa w szczególności o sytuacjach, gdy na skutek zbyt formalistycznej wykładni przepisów dochodzi do wyrządzenia istotnej szkody podatnikowi, w sytuacji, gdy ten świadomie bądź nieświadomie dopuścił się stosunkowo nieznacznego naruszenie obowiązujących przepisów prawa.
} 
nia szeroko postrzeganych sankcji skarbowych bez uzasadnionej potrzeby. Negatywne skutki decyzji wydanych bądź to w oparciu o wadliwie ustalony stan faktyczny, bądź też bez właściwie przeprowadzonego postępowania dowodowego odczuć mogli nie tylko uczciwi podatnicy, dla których wiązało się to z negatywnymi konsekwencjami, lecz także budżet państwa, który niejednokrotnie tracił strumień dochodów mogących go potencjalnie zasilić z tytułu rozwijającej się działalności podatnika.

Końcowo tezę o kluczowym znaczeniu podatku od towarów i usług dla bezpieczeństwa narodowego należy uprawdopodobnić faktem, że często działania organów mających stać na straży poprawności transakcji i rozliczeń fiskalnych na skutek wielu okoliczności błędnie typują podmioty podejrzane o fikcyjny obrót lub inne wyłudzenia. W takich przypadkach ofiarami wadliwie działającego aparatu stają się rzetelni podatnicy. Niejednokrotnie konsekwencją postępowań jest utrata płynności przez takie podmioty. Rezultaty nagannego traktowania podatników mają wiele odsłon i często skutkują przenoszeniem interesów poza granice Polski (ma to charakter bądź faktyczny, bądź tylko ukierunkowany na zmianę jurysdykcji organów podatkowych). Prowadzi to do podobnego skutku jak zjawisko uchylania się od opodatkowania, jak też do innych niekorzystnych rezultatów w postaci chociażby osłabienia gospodarki lub upadłości podatnika. Niekorzystny wpływ oszustw w podatku od towarów i usług potęguje również fakt, że obniżanie cen o równowartość podatku VAT wywołuje negatywny skutek ekonomiczny w postaci zakłócenia mechanizmów konkurencji ${ }^{23}$.

To, co jest charakterystyczne dla podatku od towarów i usług, to fakt, że podmiotami wyłudzającymi podatek VAT mogą być również podatnicy działający w sposób legalny, którzy uczestnicząc w oszustwach jedynie poprawiają swój ostateczny wynik finansowy (mowa w szczególności o podmiotach, u których wadliwe faktury stanowią

\footnotetext{
23 Przykładowo w przypadku prowadzenia działalności bez uiszczania podatku od towarów i usług.
} 
Marek Słupczewski - Luka w podatku od towarów...

nieznaczny ułamek legalnej działalności). Ogół tych czynników powoduje, że to w podatku od towarów i usług i jego niedostatecznej ściągalności należy upatrywać znacznego zagrożenia dla budżetu i tym samym pośrednio dla bezpieczeństwa narodowego.

\section{Zasadnicze problemy związane z luką w podatku od towarów i usług}

Pojęcie luki w VAT należy zdefiniować jako różnicę między oczekiwanym dochodem z tytułu podatku VAT a kwotą otrzymaną ${ }^{24}$. Wysokość tej kwoty jest szacowana corocznie na zlecenie Komisji Europejskiej ${ }^{25}$.

W doktrynie wskazuje się, że luka w podatku od towarów i usług jest pojęciem nierozerwalnie związanym $\mathrm{z}$ istotą podatku, a państwa mogą jedynie dążyć do jej jak największego zmniejszenia ${ }^{26}$.

Ze względu na fakt, że podatek od towarów i usług jest podatkiem zharmonizowanym w Unii Europejskiej, możliwe jest porównanie wysokości luki w poszczególnych państwach. Wyniki tej analizy w prosty sposób ukazują efektywność gospodarek narodowych w zakresie ściągania środków służących realizacji własnych celów, w tym również bezpieczeństwa narodowego.

Na istnienie luki podatkowej wpływa kilka zasadniczych zjawisk, między innymi takich, jak istnienie szarej strefy, optymalizacja podatkowa, oszustwa podatkowe, niska efektywność egzekucji skarbowej27.

24 „The VAT GAP is the overall difference between the expected VAT revenue and the amount actually collected" - VAT GAP Report September 2017, European Commission, the fact sheet, https://ec.europa.eu/taxation_customs/sites/taxation/files/ vat_gap_factsheet_2017.pdf [dostęp: 20-02-2018].

25 T. Tratkiewicz, Luka w Vat - sposoby..., op. cit., s. 186.

26 T. Budzyński, Fiskalne aspekty..., op. cit., s. 617.

27 E. Małecka-Ziembińska, Luka w podatku od towarów i usług oraz sposoby jej ograniczania, Szkoła Główna Handlowa, „Kwartalnik Kolegium Ekonomiczno-Społecznego Studia i Prace” 2017, nr 1, s. 46. 
Wykres 2. Wysokość luki w podatku od towarów i usług w poszczególnych krajach unijnych w 2015 r.

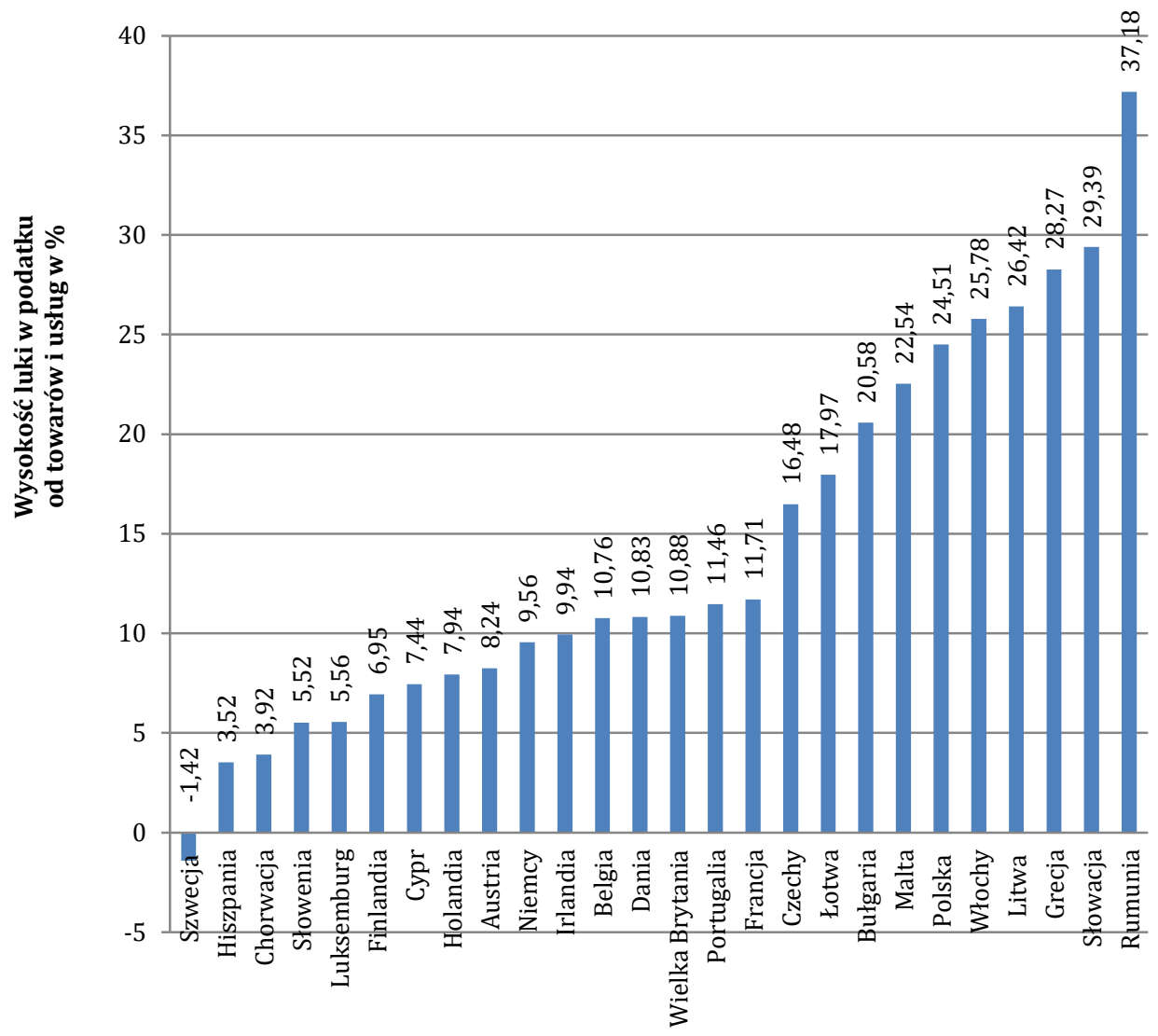

Państwa członkowskie Unii Europejskiej

Źródło: opracowanie własne na podstawie danych Komisji Europejskiej28.

Analiza wskazanego powyżej wykresu wskazuje na niechlubną pozycję Polski w czołówce państw najgorzej radzących sobie z luką w podatku od towarów i usług. W 2015 r. Polska zajmowała szóstą po-

28 Raport Komisji Europejskiej, 2015 r. https://ec.europa.eu/taxation_customs/ business/tax-cooperation-control/vat-gap_en [dostęp: 22-02-2018]. 
Marek Słupczewski - Luka w podatku od towarów...

zycję pod względem wysokości wyłudzonych przez podatników kwot podatku VAT i tym samym lepszą od tylko kilku innych państw członkowskich.

\section{Uszczuplenia budżetowe z tytułu luki w podatku od towarów i usług i ich znaczenie dla finansowania wydatków na zapewnienie bezpieczeństwa narodowego}

Bezpieczeństwo ekonomiczne Polski stanowi jeden z elementarnych składników ogólnego bezpieczeństwa narodowego. Zagadnienie to wiązać należy ze środkami publicznymi, tzn. finansami, którymi dysponują instytucje publiczne, a które stanowią podstawowe źródło finansowania wydatków służących do wykonywania zadań publicznych. Wyróżnia się dochody podatkowe i niepodatkowe ${ }^{29}$.

Dlaczego wysokość luki podatkowej ma ogromne znaczenie z punktu widzenia budżetowego i $\mathrm{w}$ dalszym ciągu $\mathrm{z}$ bezpieczeństwa narodowego? W różnych krajach dochody budżetowe $\mathrm{z}$ tytułu podatku od towarów i usług mają różne znaczenie. W Polsce, jak zostało wykazane $\mathrm{w}$ toku wywodu, dochody z tego tytułu stanowią prawie połowę budżetu. Prosty rachunek pozwala wykazać, że całkowita likwidacja luki w podatku VAT, która w 2017 r. w Polsce wyniosła ok. 39 miliardów złotych ${ }^{30}$ wobec budżetu w wysokości 325 mld złotych, pozwoliłaby (przy zachowaniu aktualnej struktury wydatków) na bardziej efektywne o ponad 10\% wykonanie zadań.

Wysokość luki podatkowej wyniosła ponad $25 \%$ wpływów z tytułu tego podatku i w latach 2007-2014 r. wzrosła pięciokrotnie. W 2012 r. przekroczyła poziom alarmowy ${ }^{31}$.

Co więcej, podliczając utratę dochodu z tytułu VAT w okresie od 2008 r. do 2015 r. ${ }^{32}$, wskazać należy, że wyniosła ona w sumie 262

\footnotetext{
${ }^{29}$ Kotowska Elżbieta, Ochrona interesów..., op. cit., s. 222.

30 Raport PWC, Warszawa 2017 r., https://www.pwc.pl/pl/media/2017/201710-19-pwc-luka-vat-2017.html [dostęp: 22-02-2018].

31 T. Budzyński, Fiskalne aspekty ..., op. cit., s. 618.
} 
miliardy złotych. Oznacza to w uproszczeniu, że w 10 letnim okresie Polska utraciła dochody w wysokości prawie jednorocznego budżetu.

Wykres 3. Porównanie wydatków budżetowych na poszczególne działy z wysokością luki w VAT w 2017 r.

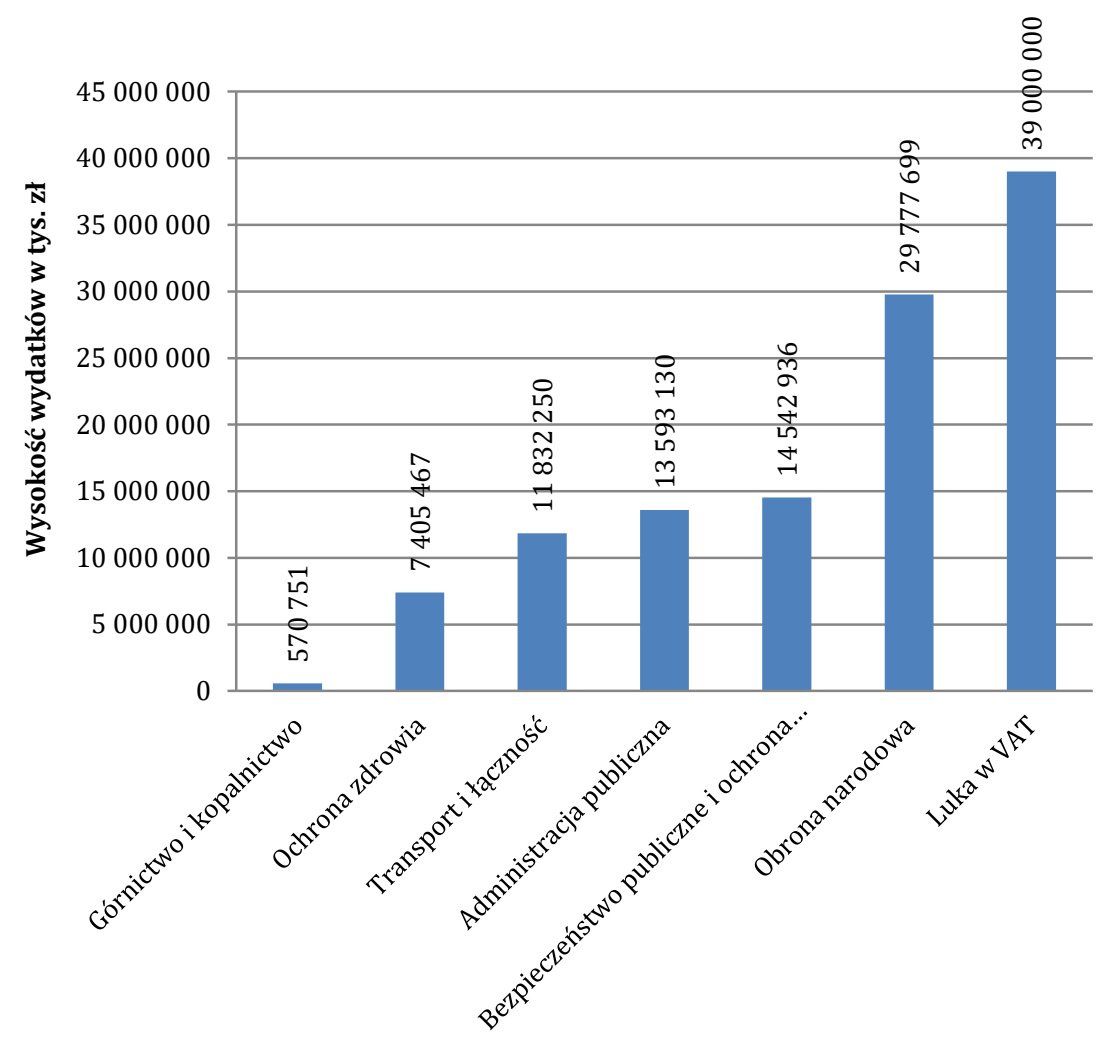

Źródło: Opracowanie własne na podstawie ustawy budżetowej na 2017 r.

Celem efektywnego powiązania pojęcia luki w podatku od towarów i usług z zagadnieniem bezpieczeństwa narodowego należy porównać kwotę uszczupleń budżetowych z tytułu podatku VAT z po-

\footnotetext{
$32 \mathrm{http}: / /$ tvn24bis.pl/pieniadze,79/ministerstwo-finansow-luka-w-podatkach-wy niosla-262-mld-zl,763422.html [dostęp: 22-02-2018].
} 
Marek Słupczewski - Luka w podatku od towarów...

szczególnymi wydatkami sprzyjającymi jego zapewnieniu. Pokazane zostało to na wykresie 3.

$\mathrm{Z}$ analizy przedstawionego powyżej wykresu wynika, że luka podatkowa osiąga równowartość corocznie przeznaczanych wydatków na ochronę zdrowia i obronę narodową, tj. w prostym ujęciu dwa najbardziej istotne filary bezpieczeństwa narodowego. Pogląd ten wydaje się uprawniony z tego względu, że wydatki w tych działach oferują podstawową prewencję zarówno dla obywateli, jak i dla terytorium i infrastruktury. Łatwo sobie wyobrazić korzyści płynące z poprawy ściągalności podatku VAT. W tym przypadku oznaczałoby to podwojenie wydatków na strategiczne dziedziny i w efekcie podwójną liczbę darmowych badań dla obywateli, zwiększoną dostępność do służby zdrowia. Rezultatem byłyby lepiej dofinansowane wojska obronne, flota morska i powietrzna. Bardziej efektywne ściągnięcie podatku VAT umożliwiłoby dokonanie lepszej redystrybucji środków. Wysokość luki można również porównać do trzykrotności rocznych wydatków na administrację publiczną.

Poprawa ściągalności VAT mogłaby zostać przeznaczona na zmniejszenie deficytu budżetowego (mogłoby to skutkować nawet zaistnieniem nadwyżki), kosztów obsługi długu publicznego. Umożliwiłaby przykładowo przyśpieszenie badań mających na celu poszukiwanie niezależnych od państw trzecich źródeł energetycznych. Korzyści płynące z efektywnego zasilenia budżetu środkami o równowartości chociażby połowy luki w podatku VAT byłyby ogromne.

\section{Powstawanie luki w podatku od towarów i usług oraz podejmowane próby jej ograniczenia}

Część podatników bardzo dobrze opanowała techniki wyłudzeń podatku VAT. Najbardziej znaną techniką jest tzw. karuzela vatowska33. Powszechny jest pogląd, że mechanizm „karuzeli” może znaleźć

\footnotetext{
${ }^{33}$ Karuzela vatowska z założenia jest działaniem kilku podmiotów, które pozorują legalne transakcje, których to celem jest jednak wyłudzenie podatku VAT.
} 
zastosowanie do niemal każdego rodzaju towaru. Oczywistym jednak jest, że najpopularniejszymi były te, w których wykorzystywano sprzęt elektroniczny ze względu na jego niewielkie gabaryty i znaczną wartość. Innym typem wyłudzeń jest wystawianie tzw. pustych faktur i uwzględnianie ich w rozliczeniach. Puste faktury dzieli się na puste przedmiotowo i podmiotowo. Te pierwsze to faktury, które nie mają żadnego odzwierciedlenia w rzeczywistości, towar wskazany na fakturze bowiem nigdy nie dotarł do nabywcy. Innym typem są faktury puste podmiotowo, tj. takie, w których niezgodność wystąpiła jedynie po stronie uczestników transakcji.

Polski ustawodawca podejmuje wiele działań celem poprawy ściągalności podatku od towarów i usług. Przybiera to różne postaci, takie jak chociażby wprowadzenie systemu odwrotnego obciążenia i obejmowanie nim kolejnych towarów i usług (z dziedzin najbardziej podatnych na wyłudzenia) ${ }^{34}$. Zaproponowano również inne rozwiązania, które aktualnie znajdują się na różnym stopniu wdrożeniowym, takie jak jednolity plik kontrolny czy też split payment ${ }^{35}$. Zmieniano również kilkukrotnie zasady odliczania podatku VAT od pojazdów używanych w działalności. Niektóre rozwiązania przyjmowały postać modyfikacji przepisów postępowania, przykładowo w postaci braku obowiązku zawiadamiania podatnika o wszczęciu wobec niego postępowania kontrolnego w przypadku, gdy w ocenie organów wystąpiła konieczność przeciwdziałania popełnieniu przestępstwa lub wykroczenia ${ }^{36}$. Mimo wielu podejmowanych prób problem luki w podatku od towarów i usług nadal występuje i stanowi zagrożenie dla funkcjonowania państwa.

\footnotetext{
34 Odwrotne obciążenie wiąże się z przeniesieniem odpowiedzialności za rozliczenie podatku od towarów i usług za transakcję ze sprzedawcy na nabywcę.

${ }^{35}$ Split payment oznacza model podzielonej płatności. Do jego istoty należy wyodrębnienie kwoty podatku VAT i przekazanie jej na wyodrębniony rachunek kontrahenta, do którego ten ma ograniczony dostęp.

${ }^{36}$ Art. 79 ust. 2 pkt 2 ustawy z dnia 2 lipca 2004 r. o swobodzie działalności gospodarczej (tekst jednolity z dnia 8 listopada 2017 r., Dz. U. 2017 r., poz. 2168). Obecnie kwestię tę regulują przepisy ustawy z dnia 6 marca 2018 r. Prawo przedsiębiorców (Dz. U. 2018 r., poz. 646).
} 
Marek Słupczewski - Luka w podatku od towarów...

\section{Podsumowanie}

W literaturze wskazuje się, że do przeciwstawienia się przez państwo zewnętrznym zagrożeniom niezbędne są takie czynniki, jak silne przywództwo, rozwinięta dyplomacja, silna gospodarka, właściwa organizacja państwa ${ }^{37}$. Przykładów tych można wskazać znacznie więcej, lecz zasadniczą konkluzją jest fakt, że bez zagwarantowania środków na wydatki służące ich zapewnieniu nie będzie możliwą ich skuteczna realizacja. Uszczuplenia budżetu w jakiejkolwiek postaci skutkują bowiem negatywnymi konsekwencjami z punktu widzenia bezpieczeństwa narodowego.

Podatki stanowią instrument, który w rozumieniu państwowego kolektywu sprzyja możliwości spełnienia jednej z podstawowych potrzeb, potrzeby bezpieczeństwa. Z drugiej strony to właśnie wskutek niesłusznych w ocenie podatnika podatków jednostka niejednokrotnie może odczuwać wrażenie pokrzywdzenia, w sytuacji gdy system podatkowy (co gorsza, w powiązaniu z niewydolnym aparatem państwa objawiającym się $\mathrm{w}$ marnotrawieniu środków publicznych) dodatkowo potęguje te wrażenia. Najważniejszą jednak przyczyną utraty dochodów budżetowych są przestępstwa gospodarcze, które najsilniej objawiają się w przypadku podatku od towarów od usług. Polska w rankingu utraconych dochodów z tytułu działalności przestępczej plasuje się niezwykle wysoko.

Luka w VAT wywołuje bardzo niekorzystne skutki budżetowe, co w bezpośredni sposób przekłada się na ograniczenie możliwości zapewnienia bezpieczeństwa narodowego. W toku wywodu zostało wskazane, że uszczuplenia wynoszą ponad $10 \%$ rocznego budżetu. Nietrudno zaś sobie wyobrazić potencjalne korzyści wynikające z zaangażowania odzyskanych środków dla dbałości o bezpieczeństwo narodowe.

Z praktyki wynika, że mimo wielu prób swoistego „spacyfikowania" podatku od towarów i usług nieznająca granic kreatywność pod-

37 W. Kitler, Bezpieczeństwo narodowe..., op. cit., s. 5. 
miotów zainteresowanych wyłudzeniami nie pozwoli na wyeliminowanie luki podatkowej w podatku od towarów i usług. Sytuację pogarsza fakt, że budżetowe znaczenie podatku od towarów i usług stale wzrasta i aktualnie osiągnął on już znaczny udział w dochodach budżetowych. Przy zachowaniu aktualnej tendencji polegającej na wzrastającym uzależnieniu dochodów budżetowych od wpływów z podatku od towarów i usług oraz wysokim udziale luki podatkowej w przyszłości może dojść do zagrożenia finansowania podstawowych zadań państwa. Warto zauważyć jednak, że w wyniku podejmowania licznych aktywności mających przeciwdziałać omawianemu zjawisku aktualnie udało się ten negatywny trend odwrócić i w najbliższym okresie można spodziewać się zmniejszenia rozmiaru luki podatkowej. Na obecnym etapie nie można jednak ostatecznie przesądzić, czy zmiana trendu ma charakter trwały.

\section{Bibliografia:}

Budzyński T., Fiskalne aspekty podatku od towarów i usług w Polsce, w „Annales Universitatis Marie Curie-Skłodowska Lublin - Polonia 2016”, vol L, 1, Sectio H.

Dworecki S., Zagrożenia bezpieczeństwa państwa, Wyd. AON, Warszawa 1994.

Jamróz P., Luka w podatku od towarów i usług - zagrożenia i kierunki zmian polityki fiskalnej w strefie euro i w Polsce, Uniwersytet Gdański Wydział Ekonomiczny Sopot, 2015.

Gregory M., Taylor M., Mikroekonomia, Polskie Wydawnictwo Ekonomiczne, Warszawa 2009.

Kitler W., Bezpieczeństwo narodowe, Podstawowe kategorie, dylematy pojęciowe i próba systematyzacji, Towarzystwo Wiedzy Obronnej, Zeszyt Problemowy 2010, nr 1 (61).

Komisja Europejska - Komunikat prasowy, Luka w podatku VAT: Kraje UE straciły w 2015 r. 152 mld euro, co wskazuje na pilna potrzebę reformy VAT Bruksela, 28 września 2017.

Kotowska E., Ochrona interesów finansowych państwa w zakresie dochodów publicznych w świetle polskich regulacji „antyrajowych” [w:] R. Szynowski, 
Marek Słupczewski - Luka w podatku od towarów...

M. Karpiuk (red.), Bezpieczeństwo narodowe Rzeczpospolitej Polskiej w świetle prawa wewnętrznego i międzynarodowego, Warszawa 2011.

Kowalski D., Współczesne aspekty bezpieczeństwa ekonomicznego państwa [w:] R. Szynowski, M. Karpiuk (red.), Bezpieczeństwo narodowe Rzeczpospolitej Polskiej w świetle prawa wewnętrznego i międzynarodowego, Warszawa 2011.

Małecka-Ziembińska E., Luka w podatku od towarów i usług oraz sposoby jej ograniczania [w:] Kwartalnik Kolegium Ekonomiczno-Społecznego Studia i Prace' Szkoła Główna Handlowa, nr 1, Warszawa 2017.

Ministerstwo Spraw Wewnętrznych i Administracji, Raport o bezpieczeństwie w Polsce w 2015 r., Warszawa 2015.

Ministerstwo Spraw Wewnętrznych i Administracji, Raport o bezpieczeństwie w Polsce w 2016 r., Warszawa 2016.

Odpowiedź podsekretarza stanu w Ministerstwie Finansów, p. M. Grabowskiego, z upoważnienia ministra z dnia 5.10.2012 r. na interpelację $\mathrm{nr}$ 8642 w sprawie luki podatkowej w podatku od towarów i usług oraz strat finansowych $\mathrm{w}$ związku $\mathrm{z}$ nią poniesionych, http://sejm.gov.pl/ sejm7.nsf/InterpelacjaTresc.xsp?key=6E824DDC [dostęp: 24-02-2018].

PwC, Luka podatkowa w VAT - jak to zwalczać?, Warszawa 2014, https://www.pwc.pl/pl/publikacje/assets/luka-podatkowa-w-vat-jak-tozwalczac-raport-pwc-2014-01-14.pdf [dostęp: 24-02-2018].

PwC, Straty Skarbu Państwa w VAT, Warszawa 2013, https://www.pwc.pl/ pl/publikacje/assets/pwc_straty_skarbu_panstwa_w_vat.pdf [dostęp: 2402-2018].

Raport PWC, Warszawa 2017 r., https://www.pwc.pl/pl/media/2017/201710-19-pwc-luka-vat-2017.html [dostęp: 24-02-2018].

Schneider F., Raczkowski K., Sfera nieoficjalna w gospodarce, „Infos” 2013, nr 21.

Tratkiewicz T., Luka w Vat - sposoby przeciwdziałania w Polsce i Unii Europejskiej, Ministerstwo Finansów Departament Podatku od towarów i usług, Studia Ekonomiczne, „Zeszyty Naukowe Uniwersytetu Ekonomicznego w Katowicach" 2016, nr 294. 